OPEN ACCESS

Edited by: Annette Gaertner, Evotec, Germany

Reviewed by:

Pirta Elina Hotulainen, Minerva Foundation Institute for Medical Research, Finland Elisa D'Este,

Max Planck Institute, Germany

*Correspondence: Marina Mikhaylova, marina.mikhaylova@zmnh.unihamburg.de

Received: 28 February 2017 Accepted: 05 May 2017 Published: 18 May 2017

Citation:

Konietzny A, Bär J and Mikhaylova M (2017) Dendritic Actin Cytoskeleton: Structure, Functions, and Regulations. Front. Cell. Neurosci. 11:147. doi: 10.3389/fncel.2017.00147

\section{Dendritic Actin Cytoskeleton: Structure, Functions, and Regulations}

\author{
Anja Konietzny, Julia Bär and Marina Mikhaylova* \\ DFG Emmy Noether Group 'Neuronal Protein Transport,' Center for Molecular Neurobiology (ZMNH), University Medical \\ Center Hamburg-Eppendorf, Hamburg, Germany
}

Actin is a versatile and ubiquitous cytoskeletal protein that plays a major role in both the establishment and the maintenance of neuronal polarity. For a long time, the most prominent roles that were attributed to actin in neurons were the movement of growth cones, polarized cargo sorting at the axon initial segment, and the dynamic plasticity of dendritic spines, since those compartments contain large accumulations of actin filaments (F-actin) that can be readily visualized using electron- and fluorescence microscopy. With the development of super-resolution microscopy in the past few years, previously unknown structures of the actin cytoskeleton have been uncovered: a periodic lattice consisting of actin and spectrin seems to pervade not only the whole axon, but also dendrites and even the necks of dendritic spines. Apart from that striking feature, patches of F-actin and deep actin filament bundles have been described along the lengths of neurites. So far, research has been focused on the specific roles of actin in the axon, while it is becoming more and more apparent that in the dendrite, actin is not only confined to dendritic spines, but serves many additional and important functions. In this review, we focus on recent developments regarding the role of actin in dendrite morphology, the regulation of actin dynamics by internal and external factors, and the role of F-actin in dendritic protein trafficking.

Keywords: dendrites, actin, cytoskeleton, protein trafficking, Arp2/3-complex, formin, cofilin

\section{INTRODUCTION}

The unique ability of neurons to compute and allocate information relies on their polarized morphology, which comprises several functionally distinct compartments. Dendrites are long, highly branched extensions from the cell body that can reach hundreds of microns, forming a widespread and complex arbor. They integrate information from typically thousands of synaptic inputs, which is then further transmitted via the cell body to the neuron's single axon (Magee, 2000; Gulledge et al., 2005). Dendrites can be morphologically and functionally sub-compartmentalized, particularly in pyramidal neurons (Shah et al., 2010; Yuan et al., 2015). One of the critical aspects in establishment and maintenance of the dendritic structure is the well-controlled turnover of cytoskeletal elements (Tsaneva-Atanasova et al., 2009). F-actin and microtubules (MTs) are the main mediators of neuronal polarity. Their organization is spatially and temporally controlled by numerous actin binding proteins (ABPs) and microtubule associated proteins, which extensively interact and feed back to each other (Georges et al., 2008; Coles and Bradke, 2015). The process of neuronal polarization is largely driven by an intrinsic program (Horton et al., 2006), however, 
this program is subject to modification by diverse environmental stimuli, including synaptic activity, that can rapidly feed back to the cytoskeleton. In light of novel discoveries related to the role and organization of neuronal F-actin, in this review we will focus on the mechanisms and molecular players that fine-tune the actin cytoskeleton, thereby controlling dendrite morphology and function.

\section{ORGANIZATION OF F-ACTIN IN DENDRITES}

Actin filaments can be arranged in linear or in branched conformations, and together with stable MT arrays and neurofilaments they form the cytoskeleton in dendrites (Yuan et al., 2012; Sainath and Gallo, 2014). Perhaps the most striking F-actin-based structures in dendrites are so-called spines, small membranous protrusions that harbor synapses. F-actin arrangement within spines is very dynamic and is subject to constant activity-dependent remodeling (Okamoto et al., 2004). Apart from that, additional F-actin based structures within the shafts of dendrites have been discovered more recently: actin patches, longitudinal fibers, and rings (Figures 1A,B). Actin patches are areas of a few microns enriched in branched F-actin (Willig et al., 2014), and were suggested to serve as outgrowth points for filopodia (Korobova and Svitkina, 2010). Longitudinal actin fibers are long bundles of F-actin that traverse along the lengths of dendrites (D'Este et al., 2015; Bär et al., 2016). Their properties and functions are so far unexplored. Actin rings, originally described in axons (Xu et al., 2013), are periodic cortical actin structures that are also present in dendrites and in necks of dendritic spines (D'Este et al., 2015; Bär et al., 2016; He et al., 2016). According to the current model, this periodic lattice consists of several short and stable actin filaments, capped by $\alpha$-adducin, and crosslinked by $\alpha / \beta$-spectrin tetramers that define the spacing between the rings (Xu et al., 2013; Qu et al., 2016). These structures are thought to support neurite shape, help in organization of proteins along the plasma membrane (Xu et al., 2013), stabilize the underlying MT cytoskeleton (Qu et al., 2016) and could influence spine neck elasticity during transport of organelles (Bär et al., 2016).

\section{REGULATION OF DENDRITIC ACTIN CYTOSKELETON}

\section{Controlling F-Actin Turnover: Actin Nucleation Factors, Severing and Capping Proteins}

Like in any other cell, many functions of actin in neurons relate to its ability to polymerize and depolymerize in response to cellular signaling. Although not specifically studied in dendrites, numerous ABPs are known that cooperate in controlling the structure and stability of F-actin networks and their ability to shape cellular membranes. A summary can be found in Table 1, whereas in the text below we will focus on the mechanisms that may be particularly relevant in the regulation of dendritic F-actin.

As the rate-limiting step in actin polymerization, nucleation is a crucial point in regulating F-actin dynamics. Several actin nucleators, including the Arp2/3-complex, WASP-homology-2 (WH2) domain proteins and formin-homology $(\mathrm{FH})$ proteins, facilitate this process. The Arp2/3-complex is the only known regulator for actin branching. It requires an existing actin filament, from which it nucleates a new filament branch (Smith et al., 2013). The Arp2/3-complex is activated by membrane-associated interactors, such as neuronal WiskottAldrich Syndrome protein (N-WASP) or WASP-family verprolin-homologous protein (WAVE) (Korobova and Svitkina, 2010). Arp2/3-complex-dependent polymerization of branched actin networks generates widespread pushing forces against the plasma membrane, accounting for its prominent role in the maturation and enlargement of dendritic spines (Bosch et al., 2014; Spence et al., 2016). Another mechanism of activation involves the F-actin binding protein cortactin, which can bind and activate the Arp2/3-complex both directly and indirectly via N-WASP (Kowalski et al., 2005; Korobova and Svitkina, 2008). The Arp2/3-complex and cortactin are enriched in both axonal and dendritic growth cones of young hippocampal neurons (Strasser et al., 2004) and in dendritic spines of mature neurons (Hering and Sheng, 2003). While overexpression of Arp2/3-complex subunits or N-WASP affect both dendrite and axon development, a deficiency of those proteins induces excessive growth and branching exclusively of the axon (Strasser et al., 2004; Pinyol et al., 2007). Dendritic phenotypes seen at the later stages of development are mostly related to attenuated filopodia and spine formation (Spence et al., 2016). The precise molecular mechanisms behind such differential effects have yet to be elucidated (Sainath and Gallo, 2014). Still, it hints at a functional redundancy with other actin nucleators specific to dendrite development. Here, elaboration critically depends on the WH2-domain nucleator Cobl (Ahuja et al., 2007), which acts as a positive regulator of neurite outgrowth and branching in rat primary hippocampal neurons (Hou et al., 2015).

Formins are actin nucleators downstream of Rho-GTPases (Matusek et al., 2008; Kühn and Geyer, 2014). They nucleate unbranched actin filaments and are mainly associated with the outgrowth of filopodia (Hotulainen et al., 2009). Additionally, they play a role in coordinating MT functions, since they have a distinct MT bundling activity (Bartolini et al., 2008). Formins are involved in proper axon development (Matusek et al., 2008), and in the formation of a deep actin network within the axon, where actin filaments are nucleated from the surface of stationary endosomes in so-called "F-actin hotspots" (Ganguly et al., 2015). Whether the same mechanism is behind the formation of F-actin patches and longitudinal F-actin bundles that have been observed in dendrites (D'Este et al., 2015; Sidenstein et al., 2016) is unknown. Interestingly, another WH2-domain nucleator, Spire (Spir-1/2), directly interacts with the formins Fmn-1/2 (Pechlivanis et al., 2009). It was shown that in several nonneuronal cell types, those two proteins are recruited to recycling endosomes and cooperate in the nucleation of F-actin from the vesicle's surface (Schuh, 2011; Pylypenko et al., 2016). Whether 


\section{Axonal growth cone}

A

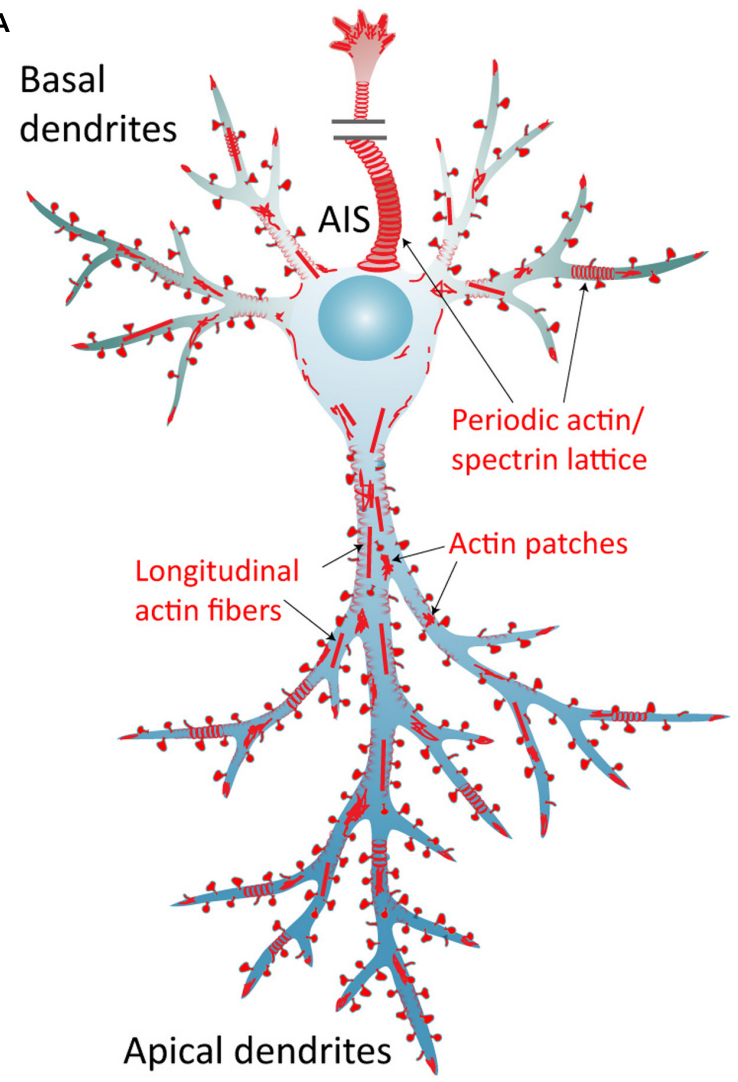

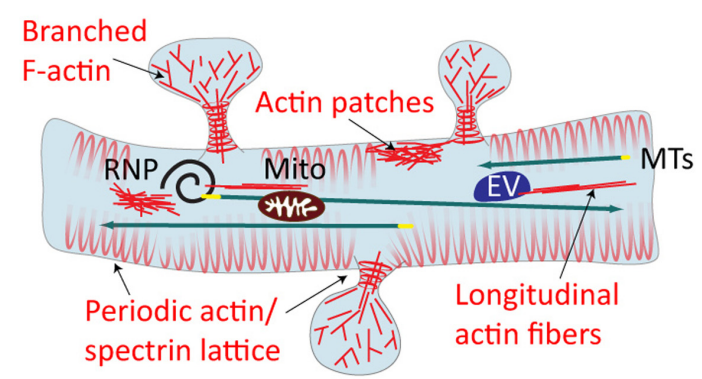

c

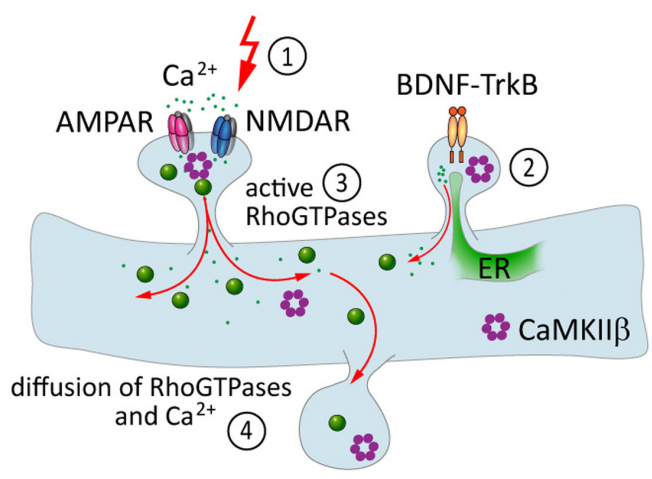

FIGURE 1 | The neuronal actin cytoskeleton and its regulation by external factors. (A) Overview of different actin structures present in pyramidal neurons: local F-actin enrichments called actin patches, longitudinal actin fibers, and a cortical periodic actin/spectrin lattice termed "actin rings" can be found throughout axon and in dendrites. (B) Dendritic spines contain branched F-actin in the head, and straight bundles as well as a periodic actin lattice in the neck. Directed transport of cargo from the soma to the dendrite is carried out via MTs, and can then be subjected to activity-dependent positioning at the base of activated spines in an F-actin and myosin-dependent manner. EV = endosomal vesicle, RNP = ribonucleoprotein, Mito = mitochondrium. (C) Dynamics of the dendritic actin cytoskeleton are influenced by external cues. Those include the transduction of external signals to the actin cytoskeleton via cell-surface receptors that couple to Rho-GEFs or ABPs, and $\mathrm{Ca}^{2+}$ signaling. The latter involves $\mathrm{Ca}^{2+}$ influx through glutamate receptors following synaptic stimulation (1), and $\mathrm{Ca}^{2+}$ release from internal stores, triggered for instance by BDNF-TrkB-signaling (2). Both pathways include the activation of Rho-GTPases (3), which act as "molecular switches" that govern a multitude of cellular functions. Diffusible factors, like $\mathrm{Ca}^{2+}$, Rho-GTPases, CaMKII $\beta$ and other downstream effectors, can spread the signal from their activation site to the dendrite and to other spines (4). ER = endoplasmatic reticulum.

this mechanism is active in neurons has not been investigated so far. However, since the expression patterns of Spire1 and Fmn-2 markedly overlap in the mouse brain (Schumacher et al., 2004), the existence of such a mechanism in neurons seems plausible.

F-actin turnover is greatly accelerated by filament severing proteins, like the closely related ADF and cofilin-1 (Sarmiere and Bamburg, 2004). They increase the number of uncapped ends that may undergo polymerization and regulate the G/F-actin pool (Andrianantoandro and Pollard, 2006). Binding of $\mathrm{ADF} /$ cofilin to F-actin additionally induces a conformational change, which can affect binding of other ABPs (Ngo et al., 2016). The activity of ADF/cofilin is tightly regulated via several mechanisms, including phosphorylation (CaMKII, LIMK) and dephosphorylation (calcineurin, slingshot). For a detailed review on ADF/cofilin, see (Kanellos and Frame, 2016). Of note, cofilin-1 activity is instrumental for the dynamic plasticity of dendritic spines (Noguchi et al., 2016), and it is possible that activated cofilin-1 could spread out from a single activated spine to drive re-organization of F-actin in associated dendritic compartments.

\section{Extracellular Factors Controlling Actin Dynamics in Dendrites}

There is a vast number of studies addressing the role of cell adhesion molecules (CAMs) and extracellular guidance cues in neuronal cell migration, axon pathfinding, axon-dendrite contact formation and dendritic spine plasticity (Togashi et al., 2009), whereas their role in dendritogenesis has been somewhat overlooked. Those cell surface receptors associate directly with ABPs, thereby translating environmental cues into local changes in actin dynamics (Leshchyns'ka and Sytnyk, 2016).

Neural CAM1 (NCAM1) has been extensively studied for its role in neuronal development (Li et al., 2013; Leshchyns'ka and 
TABLE 1 | Actin binding proteins in neurons and their cross-talk with MTs.

\begin{tabular}{|c|c|c|c|}
\hline Protein group & Function in neurons & Binding partners & Reference \\
\hline \multicolumn{4}{|c|}{ Actin monomer (G-actin) binding } \\
\hline$\beta$-Thymosin & $\begin{array}{l}\text { G-actin "buffer," blocks all known assembly reactions but } \\
\text { with a high on/off rate }\end{array}$ & & Yarmola and Bubb, 2004 \\
\hline Profilin & $\begin{array}{l}\text { Actin nucleotide exchange factor; maintains G/F-actin ratio } \\
\text { together with capping proteins }\end{array}$ & $\begin{array}{l}\text { ROCK, Formin, VASP, } \\
\text { WAVE, WASP, Drebrin }\end{array}$ & $\begin{array}{l}\text { Witke et al., 1998; Da Silva } \\
\text { et al., } 2003\end{array}$ \\
\hline CAP & $\begin{array}{l}\text { Cyclase associated protein; actin nucleotide exchange } \\
\text { factor; sequesters G-actin and severs F-actin; role in } \\
\text { growth cone and dendrite development }\end{array}$ & $\begin{array}{l}\text { Profilin, Abp1, Abl, Ras, } \\
\text { Cofilin }\end{array}$ & $\begin{array}{l}\text { Ono, 2013; Kumar et al., } \\
2016\end{array}$ \\
\hline \multicolumn{4}{|l|}{ Nucleators } \\
\hline Arp2/3-complex & $\begin{array}{l}\text { F-actin branching in lamellipodia growth cones, and spine } \\
\text { heads }\end{array}$ & WASP, WAVE, Cortactin & $\begin{array}{l}\text { Korobova and Svitkina, } \\
2008 \text {; Hotulainen et al., } \\
2009\end{array}$ \\
\hline Formins & $\begin{array}{l}\text { Filament nucleation in filopodia, growth cones and along } \\
\text { axon; synergize with other actin nucleators }\end{array}$ & $\begin{array}{l}\text { Rho, Rac, Cdc42, Spire, } \\
\text { APC }\end{array}$ & $\begin{array}{l}\text { Matusek et al., 2008; } \\
\text { Ganguly et al., } 2015\end{array}$ \\
\hline Cobl & Role in dendrite branching and growth cones & CaM, Syndapin-1 & Ahuja et al., 2007 \\
\hline Spire & $\begin{array}{l}\text { Dendrite arborization in Drosophila sensory neurons; } \\
\text { cooperates with formin-1/2; Myosin V recruitment }\end{array}$ & Formin-1/2, Myosin Vb & $\begin{array}{l}\text { Ferreira et al., 2014; } \\
\text { Pylypenko et al., } 2016\end{array}$ \\
\hline \multicolumn{4}{|c|}{ Elongation-promoting factors } \\
\hline Ena/VASP & $\begin{array}{l}\text { Accelerate elongation and prevent capping; role in filopodia } \\
\text { formation and neurite elaboration }\end{array}$ & WAVE, Profilin & $\begin{array}{l}\text { Dent et al., 2007; } \\
\text { Kwiatkowski et al., 2007; } \\
\text { Chen et al., } 2014\end{array}$ \\
\hline \multicolumn{4}{|c|}{ Barbed end capping } \\
\hline CapZ & $\begin{array}{l}\text { Maintains } G / F \text { actin ratio together with profilin; role in } \\
\text { neurite elaboration }\end{array}$ & & Davis et al., 2009 \\
\hline Adducin & $\begin{array}{l}\text { Promotes F-actin bundling and spectrin binding; } \\
\text { component of actin rings }\end{array}$ & Spectrin & Leite et al., 2016 \\
\hline \multicolumn{4}{|c|}{ Pointed end capping } \\
\hline Tropomodulins & $\begin{array}{l}\text { Stabilize F-actin and decelerate actin dynamics; associated } \\
\text { with growth cones }\end{array}$ & Tropomyosins & $\begin{array}{l}\text { Cox et al., 2003; Schevzov } \\
\text { et al., } 2012\end{array}$ \\
\hline \multicolumn{4}{|c|}{ Crosslinkers/Bundling } \\
\hline Fimbrin & Axiogenesis & Spectrin & Oprea et al., 2008 \\
\hline Spectrin & $\begin{array}{l}\text { Couples F-actin cytoskeleton to plasma membrane; } \\
\text { component of actin rings }\end{array}$ & Adducin, Fimbrin, $\alpha$-Actinin & $\begin{array}{l}\text { Bennett and Baines, 2001; } \\
\text { Xu et al., } 2013\end{array}$ \\
\hline$\alpha$-Actinin & $\begin{array}{l}\text { Calcium sensitive; role in dendrite elaboration and } \\
\text { branching }\end{array}$ & & Hodges et al., 2014 \\
\hline \multicolumn{4}{|l|}{ Severing } \\
\hline ADF/cofilin & $\begin{array}{l}\text { Bind and sever F-actin, enhance depolymerization; role in } \\
\text { spines and LTP; bind G-actin and enhance nucleation }\end{array}$ & $\begin{array}{l}\text { CaMKII, LIMK, Calcineurin, } \\
\text { Slingshot, CAP }\end{array}$ & $\begin{array}{l}\text { Meyer and Feldman, 2002; } \\
\text { Andrianantoandro and } \\
\text { Pollard, } 2006\end{array}$ \\
\hline Gelsolin & $\begin{array}{l}\text { Severs F-actin, directly activated by } \mathrm{Ca}^{2+} \text {; role in growth } \\
\text { cone and spines }\end{array}$ & $\mathrm{Ca}^{2+}$ & $\begin{array}{l}\text { Furukawa et al., 1997; Star } \\
\text { et al., } 2002\end{array}$ \\
\hline \multicolumn{4}{|l|}{ Stabilizing } \\
\hline Cortactin & $\begin{array}{l}\text { Stabilization of F-actin; activation of Arp2/3; in filopodia and } \\
\text { growth cones }\end{array}$ & Arp2/3, WASP & $\begin{array}{l}\text { Kowalski et al., 2005; } \\
\text { Korobova and Svitkina, } \\
2008\end{array}$ \\
\hline Abp1 & $\begin{array}{l}\text { Associates with newly formed, dynamic F-actin; } \\
\text { concentrated at subcortical post-synaptic scaffold }\end{array}$ & Arp2/3, WASP, Cobl & $\begin{array}{l}\text { Kessels et al., 2000; Pinyol } \\
\text { et al., } 2007\end{array}$ \\
\hline Drebrin & $\begin{array}{l}\text { Stabilizes actin, competitively inhibits binding of } \\
\text { tropomyosins, myosins, fascin and other ABPs; recruits MT } \\
\text { into growth cones and dendritic spines }\end{array}$ & EB3 & $\begin{array}{l}\text { Geraldo et al., 2008; } \\
\text { Merriam et al., } 2013\end{array}$ \\
\hline Tropomyosin & $\begin{array}{l}\text { Bind along actin filaments; role in dendrite elaboration; } \\
\text { effect depends on interaction with other ABPs }\end{array}$ & & $\begin{array}{l}\text { Schevzov et al., 2005; } \\
\text { Tojkander et al., 2011; } \\
\text { Curthoys et al., } 2014\end{array}$ \\
\hline \multicolumn{4}{|c|}{ Actin-MT crosslinkers } \\
\hline MAP1/2 & $\begin{array}{l}\text { Ability to crosslink microtubules with F-actin; formation and } \\
\text { stabilization of neurites }\end{array}$ & & $\begin{array}{l}\text { Roger et al., 2004; } \\
\text { Szebenyi et al., } 2005\end{array}$ \\
\hline
\end{tabular}


TABLE 1 | Continued

\begin{tabular}{|c|c|c|c|}
\hline Protein group & Function in neurons & Binding partners & Reference \\
\hline MACF1 & $\begin{array}{l}\text { MT-actin crosslinking factor 1, also known as ACF7, } \\
\text { Shortstop, and kakapo; Role in dendrite branching }\end{array}$ & & $\begin{array}{l}\text { Sun et al., 2001; } \\
\text { Applewhite et al., } 2010\end{array}$ \\
\hline EB3 & $\begin{array}{l}\text { MT plus-end tracking protein }(+\mathrm{TIP}) \text {; can simultaneously } \\
\text { link to actin via drebrin; role during neuritogenesis }\end{array}$ & Drebrin & Geraldo et al., 2008 \\
\hline APC & $\begin{array}{l}\text { Adenomatous polyposis coli protein; possesses actin } \\
\text { nucleation activity and might crosslink to MT via the +TIP } \\
\text { IQGAP }\end{array}$ & IQGAP, mDia & $\begin{array}{l}\text { Watanabe et al., 2004; } \\
\text { Okada et al., } 2010\end{array}$ \\
\hline Formins & $\begin{array}{l}\text { Simultaneous actin- and MT-binding activity; might also } \\
\text { crosslink actin and MT via APC:IQGAP }\end{array}$ & APC & $\begin{array}{l}\text { Bartolini et al., 2008; } \\
\text { Breitsprecher et al., } 2012\end{array}$ \\
\hline CTTNBP2 & $\begin{array}{l}\text { Cortactin-binding protein 2, neuron-specific, possible } \\
\text { interactor between cortactin and microtubules }\end{array}$ & Cortactin & Shih et al., 2014 \\
\hline CLIP170 & EB3-associated + TIP; might link MT to actin via IQGAP & IQGAP & Swiech et al., 2011 \\
\hline P140Cap & EB3-associated + TIP; might link MT to actin via cortactin & Cortactin & Jaworski et al., 2009 \\
\hline Abl & $\begin{array}{l}\text { Ableson-family of non-receptor tyrosine kinases; bind both } \\
\text { actin and MT; activate WAVE complex }\end{array}$ & WAVE, EnaNASP & $\begin{array}{l}\text { Moresco, 2005; Colicelli, } \\
2010\end{array}$ \\
\hline \multicolumn{4}{|l|}{ Motor proteins } \\
\hline $\begin{array}{l}\text { Myosin II; with light } \\
\text { chains RLC and ELC }\end{array}$ & $\begin{array}{l}\text { Network contraction; F-actin shearing; remodeling of actin } \\
\text { network in growth cones and in spines undergoing LTP }\end{array}$ & MLCK, ROCK, MLCP & $\begin{array}{l}\text { Medeiros et al., 2006; Rex } \\
\text { et al., 2010; Koskinen et al., } \\
2014\end{array}$ \\
\hline
\end{tabular}

Sytnyk, 2016). It was shown recently that the isoform NCAM180 is highly enriched at dendritic growth cones in rat primary hippocampal neurons during dendritogenesis (Frese et al., 2017). Knockdown of NCAM1 led to reduced dendrite lengths, most likely due to absence of NCAM1-mediated actin stabilization, since many different ABPs were found to be associated with its intracellular domain (Pollerberg et al., 2013; Frese et al., 2017). These results suggest a novel role of NCAM180 in dendritic arborization. Of note, other NCAM family proteins have also been reported to be involved in dendritic branching and morphology in C. elegans (Dong et al., 2013).

Integrins are another type of surface receptors in direct contact with the actin cytoskeleton. They interact with components of the extracellular matrix (ECM) and affect actin dynamics through associated Abl-family tyrosine kinases, of which Arg is particularly abundant in the nervous system and localizes to dendritic spines (Lin et al., 2013). Arg controls both dendritic spine and dendrite arbor stability through distinct pathways: it promotes binding of cortactin to F-actin to stabilize spines (MacGrath and Koleske, 2012), and attenuates Rho activity to stabilize dendrite arbors (Moresco, 2005; Lin et al., 2013).

An important feature of mature neurons is dendrite compartmentalization, for example the distinction between apical and basal dendrites, or between proximal and distal regions of apical dendrites. Those compartments are characterized by the expression of specific sets of ion channels (Ginger et al., 2013). Little is known about the mechanisms behind this distinction, however, several studies demonstrated that the large secreted matrix glycoprotein Reelin influences positioning of the Golgi apparatus toward the future apical dendrite (Leemhuis and Bock, 2011; Meseke et al., 2013), and that it is required for establishing and maintaining the molecular identity of the distal dendritic compartment of pyramidal neurons (Kupferman et al., 2014). Reelin signals through lipoprotein-receptors, activating both the
GSK3 $\beta$ - and PI3K-Rho-GTPase-pathways, which influence the MT and actin cytoskeleton, respectively (González-Billault et al., 2005; Leemhuis and Bock, 2011). Additionally, Reelin-signaling was found to inactivate ADF/cofilin via LIMK, thereby stabilizing F-actin (Chai et al., 2009, 2016).

\section{Role of Synaptic Activity in Shaping the Dendritic Actin Cytoskeleton}

Apart from direct contact with the ECM and neighboring cells, another important factor for dendrite survival and stabilization is synaptic input (Niell et al., 2004). Increased calcium influx via glutamate receptors and L-type $\mathrm{Ca}^{2+}$-channels at excitatory synapses stabilizes dendritic branches (Lohmann et al., 2002). In addition, neurotrophic signaling via brain-derived neurotrophic factor (BDNF) modulates calcium signaling. Activation of the TrkB receptor by BDNF triggers multiple downstream pathways, which promote synaptic potentiation but also dendrite growth and stabilization (Horch and Katz, 2002; Wang et al., 2015). The downstream signaling is mediated by the activation of Rac1GTPase and MAP-kinases, which influence both the actin and microtubule cytoskeleton, and of PLC- $\gamma$ and PI3-kinase, which trigger the release of calcium from the endoplasmic reticulum (ER) (reviewed in Huang and Reichardt, 2003).

Although most of the $\mathrm{Ca}^{2+}$-dependent effects have been described in spines, $\mathrm{Ca}^{2+}$ diffuses from activated spines and thus can activate dendritic targets (Figure 1C). Cytoplasmic $\mathrm{Ca}^{2+}$-signaling is largely transduced via the ubiquitous $\mathrm{Ca}^{2+}$ sensor calmodulin (CaM), which rapidly activates CaM-kinases and calcineurin ( $\mathrm{Ca}^{2+} / \mathrm{CaM}$-dependent phosphatase). CaMKII, at the center of many signaling cascades, regulates formation, growth, and branching of dendrites locally via Rho-GTPases, which modulate cytoskeleton turnover, and globally via activation of transcription factors (reviewed in Redmond and Ghosh, 2005). Apart from this, CaMKII $\beta$ possesses an F-actin binding 
ability, enabling the dodecameric holoenzyme to cross-link and stabilize actin networks (Lin and Redmond, 2008; Na et al., 2016). Activated CaMKII is then released from F-actin, which constitutes one of the many ways to link $\mathrm{Ca}^{2+}$-signaling to the regulation of the actin cytoskeleton. Several other ABPs are known to be directly influenced by $\mathrm{CaM} / \mathrm{Ca}^{2+}$, including spectrins and actinin, ADF/cofilin and gelsolin (Oertner and Matus, 2005) and Cobl (Hou et al., 2015). However, there may still be additional, so far unidentified calcium sensors that directly couple $\mathrm{Ca}^{2+}$-signaling to actin dynamics.

Numerous ABPs are further indirectly activated downstream of $\mathrm{CaM} / \mathrm{Ca}^{2+}$ and CaMKII via Rho-GTPases (Boekhoorn and Hoogenraad, 2013). Three well-studied Rho-GTPases that drive cytoskeleton-mediated dendrite morphogenesis are RhoA, Rac1 and Cdc42 (Negishi and Katoh, 2002). It was shown that during potentiation of synaptic spines, Rho-GTPases get activated and can then diffuse along the membrane into the dendrite and neighboring spines (Murakoshi et al., 2011). While this kind of "spillover" has been suggested to play a role in clustering of activated synaptic inputs (discussed in van Bommel and Mikhaylova, 2016), continued signaling within the dendritic shaft might as well be involved in activity-dependent stabilization of the whole dendrite (Figure 1C).

Rho-GTPases activate a myriad of both intertwining and antagonistic pathways that signal to the actin and microtubule cytoskeleton, their effectors including kinases, formins, MAPs, WASP-family proteins and other ABPs. For a detailed review on Rho-GTPases and their role in organizing the actin cytoskeleton, see (Sit and Manser, 2011).

\section{F-ACTIN IN TRANSPORTING AND LOCALIZATION OF CARGO WITHIN DENDRITES}

Maintenance of the polarized dendrite morphology does not only depend on the cytoskeletal scaffold, but also on the constant supply of membrane components and dendrite-specific cargo (Hanus and Ehlers, 2016). Long-range intra-dendritic cargo transport is typically carried out via MTs and associated motors. However, actin and actin-dependent motors (myosins) have been shown to mediate the transport and/or anchoring of certain cargos, which include mRNA, translational machinery and mitochondria (Ligon and Steward, 2000; reviewed in Martin and Ephrussi, 2010).

For transport, mRNA is packaged into ribonucleoprotein particles (RNPs) containing specific targeting factors, and is delivered from the soma to the dendrite via MTs. Some RNPs are targeted to spines in an activity-dependent manner, which requires the presence of F-actin (Huang et al., 2007; Yoon et al., 2016). Likewise, myosin Va (MyoVa) was shown to facilitate the accumulation of RNPs in spines (Yoshimura et al., 2006). As a general model, activity-dependent targeting of cargo to activated synapses has been proposed to involve myosins located at the spine neck, which take up cargo that has been unloaded from passing MT-motors in a $\mathrm{Ca}^{2+}$-dependent manner (Hanus et al., 2014). Similarly, it has been shown that dendritic mitochondria show activity-induced movement toward dendritic spines in dissociated neurons. This process likely involves Arp2/3-complex-mediated actin polymerization via mitochondria-associated WAVE1 (Sung et al., 2008). It has been speculated that this mechanism might ensure the local energy supply at sites of activity. However, in dendrites within intact tissues, mitochondria are mainly immobile and localize stably to synapses and branch points (Faits et al., 2016), so the in vivo role of this observation is uncertain. In this context, the possibility that actin rings could serve as cargo-docking sites has been brought up, which would allow precise control of mitochondria localization (Gallo, 2013). Supporting this, the speed of axonal mitochondria transport decreased in an $\alpha$-adducin knockout background, which affects the integrity of actin rings (Leite et al., 2016), and in axons of Drosophila neurons, knockdown of MyoV and MyoVI impacts mitochondria transport (Pathak et al., 2010).

Within the actin-rich environment of dendritic spines, myosin motors are known to play an important role in the transport of vesicular cargo (Osterweil et al., 2005; Wang et al., 2008). In cerebellar Purkinje neurons, MyoVa acts as a processive organelle transporter that moves the ER into dendritic spines, which is required for long-term synaptic depression (Wagner et al., 2011). Whether this motor is also involved in the more dynamic spine-localization of ER in other types of neurons, just like the role of myosins in transport and anchoring of dendritic organelles in general, still remains to be explored.

\section{CONCLUDING REMARKS}

Our current knowledge of the organization, polarity, and dynamics of actin along dendritic shafts is very incomplete, although the recent development of super-resolution microscopy has provided us with additional tools to study the architecture of the actin cytoskeleton in greater detail. So far, it has led to the discovery of a periodic actin lattice along the lengths of neurites, as well as actin patches and deep actin filaments, whose function and properties are still unexplored. Particularly because of the high degree of conservation among species, it would be interesting to learn more about the mechanisms and nucleation factors involved in formation and regulation of these structures.

Synaptic input and cell contacts play a critical role in the stabilization of dendrites. All of those inputs converge to finally modulate cytoskeleton dynamics, with the main effectors being MTs and F-actin. Thanks to extensive research efforts, a myriad of intertwining pathways and molecular cascades that signal to the cytoskeleton have been described. However, how a given input might lead to an observed output in such a complicated multifactor system is often hard to reconstruct in detail. Therefore, our understanding of how those different pathways are coordinated and integrated within the cell would greatly benefit from a concerted in silico modeling approach. A special interest lies on the question how and to what extent the wealth of described signaling factors that modulate F-actin dynamics within dendritic spines can extend their signaling into dendritic shafts, as a 
diffusional activity has for example been described for Rho-GTPases and cofilin.

A lot of research regarding mechanisms shaping neuronal actin networks, including their modulation by intrinsic and extrinsic signaling, has been focused on the axon, and here it is important to test whether the identified mechanisms and pathways of F-actin remodeling are applicable to dendrites as well. For example, it will be important to investigate whether dendritic F-actin patches, which at first glance appear to share a similar structure with axonal F-actin "hotspots," actually originate from stationary endosomes as well, or whether they constitute their own unique features. For now, we conclude that in analogy to the axon, the dendritic actin cytoskeleton might play a two-fold role: stable, cortical actin rings provide mechanical support, while dynamic, underlying

\section{REFERENCES}

Ahuja, R., Pinyol, R., Reichenbach, N., Custer, L., Klingensmith, J., Kessels, M. M., et al. (2007). Cordon-bleu is an actin nucleation factor and controls neuronal morphology. Cell 131, 337-350. doi: 10.1016/j.cell.2007.08.030

Andrianantoandro, E., and Pollard, T. D. (2006). Mechanism of actin filament turnover by severing and nucleation at different concentrations of ADF/Cofilin. Mol. Cell 24, 13-23. doi: 10.1016/j.molcel.2006.08.006

Applewhite, D. A., Grode, K. D., Keller, D., Zadeh, A., Slep, K. C., and Rogers, S. L. (2010). The spectraplakin short stop is an actin-microtubule cross-linker that contributes to organization of the microtubule network. Mol. Biol. Cell 21, 1714-1724. doi: 10.1091/mbc.E10-01-0011

Bär, J., Kobler, O., van Bommel, B., and Mikhaylova, M. (2016). Periodic F-actin structures shape the neck of dendritic spines. Sci. Rep. 6:37136. doi: 10.1038/ srep37136

Bartolini, F., Moseley, J. B., Schmoranzer, J., Cassimeris, L., Goode, B. L., and Gundersen, G. G. (2008). The formin mDia2 stabilizes microtubules independently of its actin nucleation activity. J. Cell Biol. 181, 523-536. doi: $10.1083 /$ jcb. 200709029

Bennett, V., and Baines, A. J. (2001). Spectrin and ankyrin-based pathways: metazoan inventions for integrating cells into tissues. Physiol. Rev. 81, 1353-1392.

Boekhoorn, K., and Hoogenraad, C. C. (2013). Regulation of AMPA-type glutamate receptor trafficking. Cell. Migr. Form. Neuronal Connect. 2, 811-822.

Bosch, M., Castro, J., Saneyoshi, T., Matsuno, H., Sur, M., and Hayashi, Y. (2014). Structural and molecular remodeling of dendritic spine substructures during long-term potentiation. Neuron 82, 444-459. doi: 10.1016/j.neuron.2014.03.021

Breitsprecher, D., Jaiswal, R., Bombardier, J. P., Gould, C. J., Gelles, J., and Goode, B. L. (2012). Rocket launcher mechanism of collaborative actin assembly defined by single-molecule imaging. Science 336, 1164-1168. doi: 10.1126/ science. 1218062

Chai, X., Fo, E., Zhao, S., Bock, H. H., and Frotscher, M. (2009). Reelin stabilizes the actin cytoskeleton of neuronal processes by inducing $\mathrm{n}$-cofilin phosphorylation at serine3. J. Neurosci. 29, 288-299. doi: 10.1523/JNEUROSCI.2934-08.2009

Chai, X., Zhao, S., Fan, L., Zhang, W., Lu, X., Shao, H., et al. (2016). Reelin and cofilin cooperate during the migration of cortical neurons: a quantitative morphological analysis. Development 1, 1029-1040. doi: 10.1242/dev.134163

Chen, X. J., Squarr, A. J., Stephan, R., Chen, B., Higgins, T. E., Barry, D. J., et al. (2014). Ena/VASP proteins cooperate with the WAVE complex to regulate the actin cytoskeleton. Dev. Cell 30, 569-584. doi: 10.1016/j.devcel.2014.08.001

Coles, C. H., and Bradke, F. (2015). Coordinating neuronal actin-microtubule dynamics. Curr. Biol. 25, R677-R691. doi: 10.1016/j.cub.2015.06.020

Colicelli, J. (2010). ABL tyrosine kinases: evolution of function, regulation, and specificity. Sci. Signal. 3:re6. doi: 10.1126/scisignal.3139re6

Cox, P. R., Fowler, V., Xu, B., Sweatt, J. D., Paylor, R., and Zoghbi, H. Y. (2003). Mice lacking tropomodulin-2 show enhanced long-term potentiation, hyperactivity, and deficits in learning and memory. Mol. Cell. Neurosci. $23,1-12$. filaments sustain physiological processes related to dendritic and synaptic plasticity.

\section{AUTHOR CONTRIBUTIONS}

$\mathrm{AK}, \mathrm{JB}$, and $\mathrm{MM}$ wrote the manuscript and all authors commented on the final version.

\section{FUNDING}

This work was supported by grants from the Deutsche Forschungsgemeinschaft (DFG Emmy-Noether Programm (Ml 1923/1-1) and FOR2419 (MI 1923/2-1).

Curthoys, N. M., Freittag, H., Connor, A., Desouza, M., Brettle, M., Poljak, A., et al. (2014). Tropomyosins induce neuritogenesis and determine neurite branching patterns in B35 neuroblastoma cells. Mol. Cell. Neurosci. 58, 11-21. doi: 10.1016/j.mcn.2013.10.011

Da Silva, J. S., Medina, M., Zuliani, C., Di Nardo, A., Witke, W., and Dotti, C. G. (2003). RhoA/ROCK regulation of neuritogenesis via profilin IIa-mediated control of actin stability. J. Cell Biol. 162, 1267-1279. doi: 10.1083/jcb. 200304021

Davis, D. A., Wilson, M. H., Giraud, J., Xie, Z., Tseng, H. C., England, C., et al. (2009). Capzb2 interacts with $\beta$-tubulin to regulate growth cone morphology and neurite outgrowth. PLoS Biol. 7:e1000208. doi: 10.1371/journal.pbio. 1000208

Dent, E. W., Kwiatkowski, A. V., Mebane, L. M., Philippar, U., Barzik, M., Rubinson, D. A., et al. (2007). Filopodia are required for cortical neurite initiation. Nat. Cell Biol. 9, 1347-1359. doi: 10.1038/ncb1654

D’Este, E., Kamin, D., Göttfert, F., El-Hady, A., and Hell, S. (2015). STED nanoscopy reveals the ubiquity of subcortical cytoskeleton periodicity in living neurons. Cell Rep. 10, 1246-1251. doi: 10.1016/j.celrep.2015. 02.007

Dong, X., Liu, O. W., Howell, A. S., and Shen, K. (2013). An extracellular adhesion molecule complex patterns dendritic branching and morphogenesis. Cell 155, 296-307. doi: 10.1016/j.cell.2013.08.059

Faits, M. C., Zhang, C., Soto, F., and Kerschensteiner, D. (2016). Dendritic mitochondria reach stable positions during circuit development. Elife 5:e11583.. doi: 10.7554/eLife.11583

Ferreira, T. A., Ou, Y., Li, S., Giniger, E., and van Meyel, D. J. (2014). Dendrite architecture organized by transcriptional control of the F-actin nucleator Spire. Development 141, 650-660. doi: 10.1242/dev.099655

Frese, C. K., Mikhaylova, M., Stucchi, R., Gautier, V., Liu, Q., Mohammed, S., et al. (2017). Quantitative map of proteome dynamics during neuronal differentiation. Cell Rep. 18, 1527-1542. doi: 10.1016/j.celrep.2017.01.025

Furukawa, K., Fu, W., Li, Y., Witke, W., Kwiatkowski, D. J., and Mattson, M. P. (1997). The actin-severing protein gelsolin modulates calcium channel and NMDA receptor activities and vulnerability to excitotoxicity in hippocampal neurons. J. Neurosci. 17, 8178-8186.

Gallo, G. (2013). More than one ring to bind them all: recent insights into the structure of the axon. Dev. Neurobiol. 73, 799-805. doi: 10.1002/dneu.22100

Ganguly, A., Tang, Y., Wang, L., Ladt, K., Loi, J., Dargent, B., et al. (2015). A dynamic formin-dependent deep F-actin network in axons. J. Cell Biol. 210, 401-417. doi: 10.1083/jcb.201506110

Georges, P. C., Hadzimichalis, N. M., Sweet, E. S., and Firestein, B. L. (2008). The yin-yang of dendrite morphology: unity of actin and microtubules. Mol. Neurobiol. 38, 270-284. doi: 10.1007/s12035-0088046-8

Geraldo, S., Khanzada, U. K., Parsons, M., Chilton, J. K., and Gordon-Weeks, P. R. (2008). Targeting of the F-actin-binding protein drebrin by the microtubule plus-tip protein EB3 is required for neuritogenesis. Nat. Cell Biol. 10, 1181-1189. doi: $10.1038 /$ ncb1778 
Ginger, M., Broser, P., and Frick, A. (2013). Three-dimensional tracking and analysis of ion channel signals across dendritic arbors. Front. Neural Circuits 7:61. doi: 10.3389/fncir.2013.00061

González-Billault, C., Del Río, J. A., Ureña, J. M., Jiménez-Mateos, E. M., Barallobre, M. J., Pascual, M., et al. (2005). A role of MAP1B in reelin-dependent neuronal migration. Cereb. Cortex 15, 1134-1145. doi: 10.1093/cercor/bhh213

Gulledge, A. T., Kampa, B. M., and Stuart, G. J. (2005). Synaptic integration in dendritic trees. J. Neurobiol. 64, 75-90. doi: 10.1002/neu.20144

Hanus, C., and Ehlers, M. D. (2016). Specialization of biosynthetic membrane trafficking for neuronal form and function. Curr. Opin. Neurobiol. 39, 8-16. doi: 10.1016/j.conb.2016.03.004

Hanus, C., Kochen, L., Tom Dieck, S., Racine, V., Sibarita, J. B., Schuman, E. M., et al. (2014). Synaptic control of secretory trafficking in dendrites. Cell Rep. 7, 1771-1778. doi: 10.1016/j.celrep.2014.05.028

He, J., Zhou, R., Wu, Z., Carrasco, M. A., Kurshan, P. T., Farley, J. E., et al. (2016). Prevalent presence of periodic actin-spectrin-based membrane skeleton in a broad range of neuronal cell types and animal species. Proc. Natl. Acad. Sci. U.S.A. 113, 6029-6034. doi: 10.1073/pnas.1605707113

Hering, H., and Sheng, M. (2003). Activity-dependent redistribution and essential role of cortactin in dendritic spine morphogenesis. J. Neurosci. 23, 11759-11769.

Hodges, J. L., Vilchez, S. M., Asmussen, H., Whitmore, L. A., and Horwitz, A. R. (2014). $\alpha$-Actinin-2 mediates spine morphology and assembly of the postsynaptic density in hippocampal neurons. PLoS ONE 9:e101770. doi: 10.1371/ journal.pone. 0101770

Horch, H. W., and Katz, L. C. (2002). BDNF release from single cells elicits local dendritic growth in nearby neurons. Nat. Neurosci. 5, 1177-1184. doi: 10.1038/ nn927

Horton, A. C., Yi, J. J., and Ehlers, M. D. (2006). Cell type-specific dendritic polarity in the absence of spatially organized external cues. Brain Cell Biol. 35, 29-38. doi: 10.1007/s11068-006-9003-y

Hotulainen, P., Llano, O., Smirnov, S., Tanhuanpää, K., Faix, J., Rivera, C., et al. (2009). Defining mechanisms of actin polymerization and depolymerization during Dendritic spine morphogenesis. J. Cell Biol. 185, 323-339. doi: 10.1083/ jcb.200809046

Hou, W., Izadi, M., Nemitz, S., Haag, N., Kessels, M. M., and Qualmann, B. (2015). The actin nucleator cobl is controlled by calcium and calmodulin. PLoS Biol. 13:e1002233. doi: 10.1371/journal.pbio.1002233

Huang, E. J., and Reichardt, L. F. (2003). Trk receptors: roles in neuronal signal transduction. Annu. Rev. Biochem. 72, 609-642. doi: 10.1146/annurev.arplant. 53.091401 .143329

Huang, F., Chotiner, J. K., and Steward, O. (2007). Actin polymerization and ERK phosphorylation are required for Arc/Arg3.1 mRNA targeting to activated synaptic sites on dendrites. J. Neurosci. 27, 9054-9067. doi: 10.1523/ JNEUROSCI.2410-07.2007

Jaworski, J., Kapitein, L. C., Gouveia, S. M., Dortland, B. R., Wulf, P. S., Grigoriev, I., et al. (2009). Dynamic microtubules regulate dendritic spine morphology and synaptic plasticity. Neuron 61, 85-100. doi: 10.1016/j.neuron.2008.11.013

Kanellos, G., and Frame, M. C. (2016). Cellular functions of the ADF/cofilin family at a glance. J. Cell Sci. 129, 3211-3218. doi: 10.1242/jcs.187849

Kessels, M. M., Engqvist-Goldstein, Å. E. Y., and Drubin, D. G. (2000). Association of mouse actin-binding protein 1 (mAbpl/SH3P7), an Src kinase target, with dynamic regions of the cortical actin cytoskeleton in response to Rac1 activation. Mol. Biol. Cell 11, 393-412. doi: 10.1091/mbc.11.1.393

Korobova, F., and Svitkina, T. (2008). Arp2/3 complex is important for filopodia formation, growth cone motility, and neuritogenesis in neuronal cells. Mol. Biol. Cell 19, 1516-1574. doi: 10.1091/mbc.E07-09-0964

Korobova, F., and Svitkina, T. (2010). Molecular architecture of synaptic actin cytoskeleton in hippocampal neurons reveals a mechanism of dendritic spine morphogenesis. Mol. Biol. Cell 21, 165-176. doi: 10.1091/mbc.E09

Koskinen, M., Bertling, E., Hotulainen, R., Tanhuanpää, K., and Hotulainen, P. (2014). Myosin IIb controls actin dynamics underlying the dendritic spine maturation. Mol. Cell. Neurosci. 61, 56-64. doi: 10.1016/j.mcn.2014.05.008

Kowalski, J. R., Egile, C., Gil, S., Snapper, S. B., Li, R., and Thomas, S. M. (2005). Cortactin regulates cell migration through activation of N-WASP. J. Cell Sci. 118, 79-87. doi: 10.1242/jcs.01586

Kühn, S., and Geyer, M. (2014). Formins as effector proteins of Rho GTPases. Small GTPases 5:e29513. doi: 10.4161/sgtp.29513
Kumar, A., Paeger, L., Kosmas, K., Kloppenburg, P., Noegel, A. A., and Peche, V. S. (2016). Neuronal actin dynamics. Spine density and neuronal dendritic complexity are regulated by CAP2. Front. Cell. Neurosci. 10:180. doi: 10.3389/ fncel.2016.00180

Kupferman, J. V., Basu, J., Russo, M. J., Guevarra, J., Cheung, S. K., and Siegelbaum, S. A. (2014). Reelin signaling specifies the molecular identity of the pyramidal neuron distal dendritic compartment. Cell 158, 1335-1347. doi: 10.1016/j.cell. 2014.07.035

Kwiatkowski, A. V., Rubinson, D. A., Dent, E. W., van Veen, J. E., Leslie, J. D., Zhang, J., et al. (2007). Ena/VASP is required for neuritogenesis in the developing cortex. Neuron 56, 441-455. doi: 10.1016/j.neuron.2007.09.008

Leemhuis, J., and Bock, H. H. (2011). Reelin modulates cytoskeletal organization by regulating Rho GTPases. Commun. Integr. Biol. 4, 254-257. doi: 10.4161/cib. 4.3.14890

Leite, S. C., Sampaio, P., Sousa, V. F., Nogueira-Rodrigues, J., Pinto-Costa, R., Peters, L. L., et al. (2016). The actin-binding protein $\alpha$-adducin is required for maintaining axon diameter. Cell Rep. 15, 490-498. doi: 10.1016/j.celrep.2016. 03.047

Leshchyns'ka, I., and Sytnyk, V. (2016). Reciprocal interactions between cell adhesion molecules of the immunoglobulin superfamily and the cytoskeleton in neurons. Front. Cell Dev. Biol. 4:9. doi: 10.3389/fcell.2016.00009

Li, S., Leshchyns'ka, I., Chernyshova, Y., Schachner, M., and Sytnyk, V. (2013). The neural cell adhesion molecule (NCAM) associates with and signals through p21-activated kinase 1 (Pak1). J. Neurosci. 33, 790-803. doi: 10.1523/ JNEUROSCI.1238-12.2013

Ligon, L. A., and Steward, O. (2000). Role of microtubules and actin filaments in the movement of mitochondria in the axons and dendrites of cultured hippocampal neurons. J. Comp. Neurol. 427, 351-361.

Lin, Y.-C., and Redmond, L. (2008). CaMKIIbeta binding to stable F-actin in vivo regulates F-actin filament stability. Proc. Natl. Acad. Sci. U.S.A. 105, 15791-15796. doi: 10.1073/pnas.0804399105

Lin, Y.-C., Yeckel, M. F., and Koleske, A. J. (2013). Abl2/Arg controls dendritic spine and dendrite arbor stability via distinct cytoskeletal control pathways. J. Neurosci. 33, 1846-1857. doi: 10.1523/JNEUROSCI.4284-12.2013

Lohmann, C., Myhr, K. L., and Wong, R. O. L. (2002). Transmitter-evoked local calcium release stabilizes developing dendrites. Nature 418, 177-181. doi: $10.1038 /$ nature 00850

MacGrath, S. M., and Koleske, A. J. (2012). Arg/Abl2 modulates the affinity and stoichiometry of binding of cortactin to F-Actin. Biochemistry 51, 6644-6653. doi: $10.1021 /$ bi300722t

Magee, J. C. (2000). Dendritic integration of excitatory synaptic input. Nat. Rev. Neurosci. 1, 181-190. doi: 10.1038/35044552

Martin, K. C., and Ephrussi, A. (2010). mRNA localization: gene expression in the spatial dimension. Cell 136, 719-730. doi: 10.1016/j.cell.2009.01.044.mRNA

Matusek, T., Gombos, R., Szécsényi, A., Sánchez-Soriano, N., Czibula, A., Pataki, C., et al. (2008). Formin proteins of the DAAM subfamily play a role during axon growth. J. Neurosci. 28, 13310-13319. doi: 10.1523/JNEUROSCI. 2727-08.2008

Medeiros, N. A., Burnette, D. T., and Forscher, P. (2006). Myosin II functions in actin-bundle turnover in neuronal growth cones. Nat. Cell Biol. 8, 215-226. doi: $10.1038 /$ ncb1367

Merriam, E. B., Millette, M., Lumbard, D. C., Saengsawang, W., Fothergill, T., $\mathrm{Hu}, \mathrm{X}$., et al. (2013). Synaptic regulation of microtubule dynamics in dendritic spines by calcium. F-actin, and drebrin. J. Neurosci. 33, 16471-16482. doi: 10.1523/JNEUROSCI.0661-13.2013

Meseke, M., Rosenberger, G., and Förster, E. (2013). Reelin and the Cdc42/Rac1 guanine nucleotide exchange factor $\alpha$ PIX/Arhgef6 promote dendritic Golgi translocation in hippocampal neurons. Eur. J. Neurosci. 37, 1404-1412. doi: $10.1111 /$ ejn. 12153

Meyer, G., and Feldman, E. L. (2002). Signaling mechanisms that regulate actinbased motility processes in the nervous system. J. Neurochem. 83, 490-503. doi: 10.1046/j.1471-4159.2002.01185.x

Moresco, E. M. Y. (2005). Integrin-mediated dendrite branch maintenance requires abelson (Abl) family kinases. J. Neurosci. 25, 6105-6118. doi: 10.1523/ JNEUROSCI.1432-05.2005

Murakoshi, H., Wang, H., and Yasuda, R. (2011). Local, persistent activation of Rho GTPases during plasticity of single dendritic spines. Nature 472, 100-104. doi: $10.1038 /$ nature09823 
Na, Y., Park, S., Lee, C., Sockanathan, S., Huganir, R. L., Worley, P. F., et al. (2016). Real-time imaging reveals properties of glutamate-induced Arc/Arg 3.1 translation in neuronal dendrites. Neuron 91, 561-573. doi: 10.1016/j.neuron. 2016.06.017

Negishi, M., and Katoh, H. (2002). Rho family GTPases as key regulators for neuronal network formation. J. Biochem. 132, 157-166.

Ngo, K. X., Umeki, N., Kijima, S. T., Kodera, N., Ueno, H., Furutani-Umezu, N., et al. (2016). Allosteric regulation by cooperative conformational changes of actin filaments drives mutually exclusive binding with cofilin and myosin. Sci. Rep. 6:35449. doi: 10.1038/srep35449

Niell, C. M., Meyer, M. P., and Smith, S. J. (2004). In vivo imaging of synapse formation on a growing dendritic arbor. Nat. Neurosci. 7, 254-260. doi: 10.1038/ nn1191

Noguchi, J., Hayama, T., Watanabe, S., Ucar, H., Yagishita, S., Takahashi, N., et al. (2016). State-dependent diffusion of actin-depolymerizing factor/cofilin underlies the enlargement and shrinkage of dendritic spines. Sci. Rep. 6:32897. doi: $10.1038 /$ srep32897

Oertner, T. G., and Matus, A. (2005). Calcium regulation of actin dynamics in dendritic spines. Cell Calcium 37, 477-482. doi: 10.1016/j.ceca.2005.01.016

Okada, K., Bartolini, F., Deaconescu, A. M., Moseley, J. B., Dogic, Z., Grigorieff, N., et al. (2010). Adenomatous polyposis coli protein nucleates actin assembly and synergizes with the formin mDia1. J. Cell Biol. 189, 1087-1096. doi: 10.1083/jcb. 201001016

Okamoto, K.-I., Nagai, T., Miyawaki, A., and Hayashi, Y. (2004). Rapid and persistent modulation of actin dynamics regulates postsynaptic reorganization underlying bidirectional plasticity. Nat. Neurosci. 7, 1104-1112. doi: 10.1038/ nn 1311

Ono, S. (2013). The role of cyclase-associated protein in regulating actin filament dynamics - more than a monomer-sequestration factor. J. Cell Sci. 126, 3249-3258. doi: 10.1242/jcs. 128231

Oprea, G. E., Kröber, S., McWhorter, M. L., Rossoll, W., Müller, S., Krawczak, M., et al. (2008). Plastin 3 is a protective modifier of autosomal recessive spinal muscular atrophy. Science 320, 524-527. doi: 10.1126/science.1155085

Osterweil, E., Wells, D. G., and Mooseker, M. S. (2005). A role for myosin VI in postsynaptic structure and glutamate receptor endocytosis. J. Cell Biol. 168, 329-338. doi: 10.1083/jcb.200410091

Pathak, D., Sepp, K. J., and Hollenbeck, P. J. (2010). Evidence that myosin activity opposes microtubule-based axonal transport of mitochondria. J. Neurosci. 30, 8984-8992. doi: 10.1523/JNEUROSCI.1621-10.2010

Pechlivanis, M., Samol, A., and Kerkhoff, E. (2009). Identification of a short spir interaction sequence at the C-terminal end of formin subgroup proteins. J. Biol. Chem. 284, 25324-25333. doi: 10.1074/jbc.M109.030320

Pinyol, R., Haeckel, A., Ritter, A., Qualmann, B., and Kessels, M. M. (2007). Regulation of N-WASP and the Arp2/3 complex by Abp1 controls neuronal morphology. PLoS ONE 2:e400. doi: 10.1371/journal.pone.0000400

Pollerberg, G. E., Thelen, K., Theiss, M. O., and Hochlehnert, B. C. (2013). The role of cell adhesion molecules for navigating axons: density matters. Mech. Dev. 130, 359-372. doi: 10.1016/j.mod.2012.11.002

Pylypenko, O., Welz, T., Tittel, J., Kollmar, M., Chardon, F., Malherbe, G., et al. (2016). Coordinated recruitment of Spir actin nucleators and myosin V motors to Rab11 vesicle membranes. Elife 5:e17523. doi: 10.7554/eLife.17523

Qu, Y., Hahn, I., Webb, S., and Prokop, A. (2016). Periodic actin structures in neuronal axons are required to maintain microtubules. Mol. Biol. Cell 28, 296-308. doi: 10.1101/049379

Redmond, L., and Ghosh, A. (2005). Regulation of dendritic development by calcium signaling. Cell Calcium 37, 411-416. doi: 10.1016/j.ceca.2005.01.009

Rex, C., Gavin, C. F., Rubio, M. D., Kramar, E. A., Chen, L. Y., Jia, Y., et al. (2010). Myosin IIB regulates actin dynamics during synaptic plasticity and memory formation. Neuron 67, 603-617. doi: 10.1016/j.neuron.2010.07.016

Roger, B., Al-Bassam, J., Dehmelt, L., Milligan, R. A., and Halpain, S. (2004). MAP2c, but not tau, binds and bundles F-actin via its microtubule binding domain. Curr. Biol. 14, 363-371. doi: 10.1016/j.cub.2004.01.058

Sainath, R., and Gallo, G. (2014). Cytoskeletal and signaling mechanisms of neurite formation. Cell Tissue Res. 359, 267-278. doi: 10.1007/s00441-014-1955-0

Sarmiere, P. D., and Bamburg, J. R. (2004). Regulation of the neuronal actin cytoskeleton by ADF/cofilin. J. Neurobiol. 58, 103-117. doi: 10.1002/neu.10267

Schevzov, G., Bryce, N. S., Almonte-Baldonado, R., Joya, J., Lin, J. J.-C., Hardeman, E., et al. (2005). Specific features of neuronal size and shape are regulated by tropomyosin isoforms. Mol. Biol. Cell 16, 3425-3437. doi: 10.1091/ mbc.E04

Schevzov, G., Curthoys, N. M., Gunning, P. W., and Fath, T. (2012). Functional diversity of actin cytoskeleton in neurons and its regulation by tropomyosin. Int. Rev. Cell Mol. Biol. 298, 33-94. doi: 10.1016/B978-0-12-394309-5.00002-X

Schuh, M. (2011). An actin-dependent mechanism for long-range vesicle transport. Nat. Cell Biol. 13, 1431-1436. doi: 10.1038/ncb2353

Schumacher, N., Borawski, J. M., Leberfinger, C. B., Gessler, M., and Kerkhoff, E. (2004). Overlapping expression pattern of the actin organizers Spir-1 and formin-2 in the developing mouse nervous system and the adult brain. Gene Expr. Patterns 4, 249-255. doi: 10.1016/j.modgep.2003.11.006

Shah, M. M., Hammond, R. S., and Hoffman, D. (2010). Dendritic ion channel trafficking and plasticity. Trends Neurosci. 33, 307-316. doi: 10.1016/j.tins.2010. 03.002.Dendritic

Shih, P., Lee, S., Chen, Y., and Hsueh, Y. (2014). Cortactin binding protein 2 increases microtubule stability and regulates dendritic arborization. J. Cell Sci. 127(Pt 16), 3521-3534. doi: 10.1242/jcs.149476

Sidenstein, S. C., D’Este, E., Böhm, M. J., Danzl, J. G., Belov, V. N., and Hell, S. W. (2016). Multicolour multilevel STED nanoscopy of actin/spectrin organization at synapses. Sci. Rep. 6:26725. doi: 10.1038/srep26725

Sit, S.-T., and Manser, E. (2011). Rho GTPases and their role in organizing the actin cytoskeleton. J. Cell Sci. 124, 679-683. doi: 10.1242/jcs.064964

Smith, B. A., Daugherty-Clarke, K., Goode, B. L., and Gelles, J. (2013). Pathway of actin filament branch formation by Arp2/3 complex revealed by singlemolecule imaging. Proc. Natl. Acad. Sci. U.S.A. 110, 1285-1290. doi: 10.1073/ pnas. 1211164110

Spence, E. F., Kanak, D. J., Carlson, B. R., and Soderling, S. H. (2016). The Arp2/3 complex is essential for distinct stages of spine synapse maturation, including synapse unsilencing. J. Neurosci. 36, 9696-9709. doi: 10.1523/JNEUROSCI. 0876-16.2016

Star, E. N., Kwiatkowski, D. J., and Murthy, V. N. (2002). Rapid turnover of actin in dendritic spines and its regulation by activity. Nat. Neurosci. 5, 239-246.

Strasser, G. A., Rahim, N. A., Vanderwaal, K. E., Gertler, F. B., and Lanier, L. M. (2004). Arp2/3 is a negative regulator of growth cone translocation. Neuron 43, 81-94. doi: 10.1016/j.neuron.2004.05.015

Sun, D., Leung, C. L., and Liem, R. K. (2001). Characterization of the microtubule binding domain of microtubule actin crosslinking factor (MACF): identification of a novel group of microtubule associated proteins. J. Cell Sci. $114,161-172$.

Sung, J. Y., Engmann, O., Teylan, M. A., Nairn, A. C., Greengard, P., and Kim, Y. (2008). WAVE1 controls neuronal activity-induced mitochondrial distribution in dendritic spines. Proc. Natl. Acad. Sci. U.S.A. 105, 3112-3116. doi: 10.1073/ pnas.0712180105

Swiech, L., Blazejczyk, M., Urbanska, M., Pietruszka, P., Dortland, B. R., Malik, A. R., et al. (2011). CLIP-170 and IQGAP1 cooperatively regulate dendrite morphology. J. Neurosci. 31, 4555-4568. doi: 10.1523/JNEUROSCI.6582-10. 2011

Szebenyi, G., Bollati, F., Bisbal, M., Sheridan, S., Faas, L., Wray, R., et al. (2005). Activity-driven dendritic remodeling requires microtubule-associated protein 1A. Curr. Biol. 15, 1820-1826. doi: 10.1016/j.cub.2005.08.069

Togashi, H., Sakisaka, T., and Takai, Y. (2009). Cell adhesion molecules in the central nervous system. Cell Adh. Migr. 3, 29-35.

Tojkander, S., Gateva, G., Schevzov, G., Hotulainen, P., Naumanen, P., Martin, C., et al. (2011). A molecular pathway for myosin II recruitment to stress fibers. Curr. Biol. 21, 539-550. doi: 10.1016/j.cub.2011.03.007

Tsaneva-Atanasova, K., Burgo, A., Galli, T., and Holcman, D. (2009). Quantifying neurite growth mediated by interactions among secretory vesicles, microtubules, and actin networks. Biophys. J. 96, 840-857. doi: 10.1016/j.bpj.2008.10.036

van Bommel, B., and Mikhaylova, M. (2016). Talking to the neighbours: the molecular and physiological mechanisms of clustered synaptic plasticity. Neurosci. Biobehav. Rev. 71, 352-361. doi: 10.1016/j.neubiorev.2016.09.016

Wagner, W., Brenowitz, S. D., and Hammer, J. A. I. (2011). Myosin-Va transports the endoplasmic reticulum into the dendritic spines of purkinje neurons. Nat. Cell Biol. 1, 40-48. doi: 10.1038/ncb2132

Wang, L., Chang, X., She, L., Xu, D., Huang, W., and Poo, M.-M. (2015). Autocrine action of BDNF on dendrite development of adult-born hippocampal neurons. J. Neurosci. 6, 8384-8393. doi: 10.1523/JNEUROSCI.4682-14.2015 
Wang, Z., Edwards, J. G., Riley, N., Provance, D. W., Karcher, R., Li, X., et al. (2008). Myosin Vb mobilizes recycling endosomes and AMPA receptors for postsynaptic plasticity. Cell 135, 535-548. doi: 10.1016/j.cell.2008.09.057

Watanabe, T., Wang, S., Noritake, J., Sato, K., Fukata, M., Takefuji, M., et al. (2004). Interaction with IQGAP1 links APC to Racl. Cdc42, and actin filaments during cell polarization and migration. Dev. Cell 7, 871-883. doi: 10.1016/j.devcel.2004. 10.017

Willig, K. I., Steffens, H., Gregor, C., Herholt, A., Rossner, M. J., and Hell, S. W. (2014). Nanoscopy of filamentous actin in cortical dendrites of a living mouse. Biophys. J. 106, L01-L03. doi: 10.1016/j.bpj.2013.11. 1119

Witke, W., Podtelejnikov, A. V., Di Nardo, A., Sutherland, J. D., Christine, B., Gurniak, et al. (1998). In mouse brain profilin I and profilin II associate with regulators of the endocytic pathway and actin assembly. EMBO J. 17, 967-976. doi: 10.1093/emboj/17.4.967

$\mathrm{Xu}, \mathrm{K}$., Zhong, G., and Zhuang, X. (2013). Actin, spectrin, and associated proteins form a periodic cytoskeletal structure in axons. Science 339, 452-456. doi: 10.1126/science.1232251

Yarmola, E. G., and Bubb, M. R. (2004). Effects of profilin and thymosin $\beta 4$ on the critical concentration of actin demonstrated in vitro and in cell extracts with a novel direct assay. J. Biol. Chem. 279, 33519-33527. doi: 10.1074/jbc. M404392200
Yoon, Y. J., Wu, B., Buxbaum, A. R., Das, S., Tsai, A., English, B. P., et al. (2016). Glutamate-induced RNA localization and translation in neurons. Proc. Natl. Acad. Sci. U.S.A. 113, E6877-E6886. doi: 10.1073/pnas.1614267113

Yoshimura, A., Fujii, R., Watanabe, Y., Okabe, S., Fukui, K., and Takumi, T. (2006). Myosin-Va facilitates the accumulation of mRNA/protein complex in dendritic spines. Curr. Biol. 16, 2345-2351. doi: 10.1016/j.cub.2006.10.024

Yuan, A., Rao, M. V., Veeranna, and Nixon, R. A. (2012). Neurofilaments at a glance. J. Cell Sci. 125, 3257-3263. doi: 10.1242/jcs.104729

Yuan, Y., Seong, E., Singh, D., and Arikkath, J. (2015). Differential regulation of apical-basolateral dendrite outgrowth by activity in hippocampal neurons. Front. Cell. Neurosci. 9:314. doi: 10.3389/fncel.2015.00314

Conflict of Interest Statement: The authors declare that the research was conducted in the absence of any commercial or financial relationships that could be construed as a potential conflict of interest.

Copyright (c) 2017 Konietzny, Bär and Mikhaylova. This is an open-access article distributed under the terms of the Creative Commons Attribution License (CC BY).

The use, distribution or reproduction in other forums is permitted, provided the original author(s) or licensor are credited and that the original publication in this journal is cited, in accordance with accepted academic practice. No use, distribution or reproduction is permitted which does not comply with these terms. 